\title{
Addiction Research
}

\section{Ethnography Study: Causes of Teenager Consume Narcotics in Papua and West Papua}

\section{Agussalim* and Masdiana AR}

Leader of Community Outreach, Health Polytechnic of Jayapura, Indonesia.

Health Polytechnic of Makassar, South Sulawesi, Indonesia.
${ }^{*}$ Correspondence:

Agussalim, Leader of Community Outreach, Health Polytechnic of Jayapura, Indonesia, Tel: 085757888449; E-mail: Salim170878@ gmail.com.

Received: 01 May 2018; Accepted: 29 May 2018

Citation: Agussalim, Masdiana AR. Ethnography Study: Causes of Teenager Consume Narcotics in Papua and West Papua. Addict Res. 2018; 2(1): 1-5.

\begin{abstract}
Objectives: Narcotics case is one of the biggest cases in this time. The government of Indonesia has conducted treatment and prophylaxis seriously. Since 2011, it has been found around 4.7 million people with addictive narcotics in Indonesia. In 2012 has been found the number of the people who consume narcotics in Papua 17,750 people or 0.8 percent of Papuans. This research aimed to understand causes of Papuans teenager consume narcotics and its support in Papua and West Papua.
\end{abstract}

Methods: This research is a qualitative research which is data collected by deep interview to understand specific Papuans of factors caused a teenager consume narcotics. This research was conducted in the prison of narcotics in Papua and West Papua.

Result: Deep interview study was identified that the main cause of a teenager consume narcotics in Papua and West Papua is friendship. They will try to use narcotics step by step as cause of friendship then addiction is happened.

Discussion: We already known the main caused of a teenager consumed narcotics in Papua and West Papua, moreover the regulation from the government must be hardly to the people who is spread and sell narcotics applied punish hardly.

Keywords

Teenager, Narcotics, Papua and West Papua, Addiction, Consumed.

\section{Introduction}

Drug case is very large case at the moment. Many countries have problem with drug and narcotics. Papua New Guinea (PNG) is a boundary country of Papua Province, Indonesia. Widespread as marijuana has become in this country, little ethnographic problem raised by its cultivation, and consumption in that country [1].

Over the past decade, marijuana becomes a significant element within PNG's communities, revealing an important connection to the broader political economy. For young men, fluctuating commodity prices, the intermittent exploitation of mineral wealth and a reluctant tourist economy only gives them a taste for development [2].
In South East Asian Country was found Myanmar was the main producer of opium, heroin, and amphetamine-type stimulants (ATS). China is now considered a major producer of methamphetamines, but other Asia-Pacific nations are also involved in production. Cannabis production was found throughout most of the Asia-Pacific region, in particular Cambodia and the Philippines. Drug trafficking and transit routes of Asia and the Pacific were proliferating and dynamic [3]. Laos was criticized by US as the third largest opium producer in the world, despite the fact that the export of opium from the country was minimal compared to Burma and Afghanistan [4].

Meanwhile, according to estimates of the National Narcotics Agency of Indonesia Authorities (BNN), there are currently approximately 5.6 million drug users. First, the materials most widely consumed were cannabis. In the second half of 1990, 
there is a sharp increase of heroin users, especially through the syringe. This resulted increase to the rapid spread of HIV/AIDS in Indonesia. But towards the end of 1990's, the most widely used is the Amphetamine Type Stimulants (ATS).

The Government of Indonesia is doing prevention seriously because of drug users reported on estimate about 3.7 million to 4.7 million drug users in Indonesia. The data for 2011 about 1.2 million people are use crystalline methamphetamine and ecstasy around 950.00 people. As a comparison, there are 2.8 million users of cannabis and about 110,000 heroin addicted.

The Government of Indonesia has designed a program to rehabilitate approximately 100,000 drug users each year. In the context of health effects from handling the abuse of drugs, there are a number of services offered, for example handling in psychosocial, counseling, group therapy counseling, and tested of HIV/AIDS, including treatment with therapeutic anti-retroviral to HIV infected.

Based on the data from BNN [5] offender by level of education majority was Elementary School until 2007 around 12,305. This data is showing so worrying because it is increasing cases of drugs (especially among the young age and children), the spread of HIV/ AIDS increased and threatened. The spread of drugs is becoming increasing easily because elementary school children also have started to dabble in sucking on a cigarette. Drug traffickers often infiltrate the addictive substances (substances that cause addiction effects) into tobacco hand-rolled. Culture diversity in a country has the big effect spreading bad behavior like hand narcotics inside the country for young people [6].

In Indonesia, the development of the drug addicts is increasing rapidly. The drug addicts were generally between the ages of 11 to 24 years. This means that the majority is productive age. At first, the students who consume drugs is usually preceded by her relationship with the cigarette smoking habit, because this seems like a reasonable thing become among the students at this time. It is a habit; the Association continues to increase, especially when the students join the neighborhood people who have become drug addicts. It was originally tried, and then experienced a dependency.

Based on the news online of Jakarta Globe [7] that was the circulation of narcotics and illegal drugs in Papua were quite high as much as 16,740 or 0.8 percent citizens in Papua involved drug abuse. The survey results based on BNN's news in 2011 to 2012 as many as 5000 people newbie, 7500 people wearers remain, 250 people are addicted to narcotic injection, with 4000 people of noninjection drug addiction. It further said that the age range 15 to 59 year's drug users with data on the age of the high school student around 173 people, convicts 47 people. While the final report from Papua Police in 2013 mentions that there were 136 cases of drugs being found in 2013 .

Statement of the problem

Based on the above data, we are interested in doing research on influential factor against drug use in teens in the Provinces of Papua and West Papua in 2017. That's way our questions research is "What is the Majority causes of teenagers in Papua and West Papua consume drugs or narcotics?"

\section{Method of research}

This research is qualitative research approach with ethnographic leverage data through in-depth interviews to find out the factor causes teenagers in Papua and West Papua consume drugs. The research was carried out for one month calculated from August until October 2017. Research was conducted at the prison of narcotics in Doyo, Regency Jayapura. It is the only Drug specifically correctional facility in the Provinces of Papua and West Papua.

The informants in this study around 8 persons with representatives of each of the 4 informant drug users at the age of adolescence with a target coming from the territory of Papua and West Papua that meet the following criteria as follow; (1) willing to become informants and speak Indonesia well in order to facilitate the interview process briefly; (2) The participants is on the location of research when data retrieval implemented; and (3) Koperatif.

Data collection is carried out with the involvement of the researcher's head of special correctional facility Drug stop at Doyo in Jayapura Regency. The interview process is not directly conducted by the researcher first met with the informant. At first, the informant interviews lasted approximately 7 hours in the correctional facility that has been determined by informants earlier. The image of a drug also served as one of the tools the introduction between researchers with informants, especially in those who initially had not yet opened in providing information. This is done due to constraints in providing related questions use of drugs. In order to get valid data then cross check against criminal records data in a correctional facility as well as with the head of the unit on drug type of prison they consume. Informants in this study remained guarded identity secrecy of its name by wearing the initials birds (pigeons, cenderawasih, etc.) and those that address his home ever disguised.

\section{Validity of data}

To test the credibility of the data conducted by the way check the data that has been obtained through Tri angulation source i.e. with comparing the information the informant (cross checking) between the information with each other. In looking at the accuracy of the information obtained in this research, the sources do not only come from drug users, but also with drug-related criminal records as well as informant of correctional substance abuse.

\section{Processing and analysis of data}

According to Miles and Huberman [8], suggests that the analysis of qualitative data is done interactively and lasted continuously until finished. Activities in the analysis of the data are namely data reduction, data display, and conclusion drawing verification.

1. Data reduction (reduction of data), reduction of data means to encapsulate, choosing things; focus on the things that are most 
important, look for themes and pattern. The data has been reduction will provide a clearer picture and ease the researchers to perform further data collection.

2. Data display (Presenting data), according to Miles and Huberman States that the most frequent digunalkan to present data in qualitative research is a narrative that is by text.

3. Conclusion drawing verification, the next step, namely the verification conclusion and withdrawal. Preliminary conclusions expressed are still temporary. If the conclusion from the beginning supported by evidence of a valid and consistent when researchers gather data, then the conclusions put forward a credible conclusion is $[8]$.

\section{Results}

This chapter describes the causes of teenagers in Papua from either newcomers or original Papuans used drugs such as cannabis, Shabu-Shabu or Pill PCC which is currently circulating in much of Indonesia. This research resulted in two very important themes: first is the main cause of teen consumes drugs in Papua and West Papua. The second theme is a factor supporting the cause of teen consume drug in Papua and West Papua.

The Description of the characteristics of the place research The Study has been done at the correctional facility Drug Class IIA at Doyo, Jayapura Regency, Papua Province. Correctional facility is under the control of the Ministry of Justice and Human Rights of Republic of Indonesia. This is a special drug prison agency oversees territory of Papua and West Papua. The numbers of occupants in the prison are around 344 inmates with drug cases as a user or dealer at once. Each resident was a convict already which convicted by a court in consequence of the use or distribute drugs and the like. Based on data from the head of the correctional facility said that more than $60 \%$ percent is the age of the adolescents, the rest is the age of majority and age of more than 60 years.

The Description of the characteristics of participants

As many as 8 participants participated in this study; all the participants are men with ages between 17 to 21 years. 3 people are newcomers and 5 people were the son of original Papuan. From any participant in this study, The majority of them are children dropping out of school or had worked as laborers building, the loading section and at the airport. The Participants in this research which are since a long time been using drugs when he was still the age of Junior High School.

\section{Analysis of themes}

Based on the results of in-depth interviews and observations by using the notes field during data capture process, then the researcher doing data analysis using a content analysis developed by Collaizi, 1978 [9]. This section describes in detail the theme description are identified from the results of the interview. The themes are: (1) the main causes of them consumed drugs (2); the factors supporting their cause of them consumed drugs. Each theme will be described one by one.

Theme 1: Main causes of teen consumed drug in Papua and
West Papua. This theme is obtained in order to answer the first special-purpose obtain information in depth will be a major theme underlying them using drugs. Drug use by them based on several things in accordance with the results of the talks and indepth interviews that have been done to the appropriate theme that participant said that

"I used drugs since junior high school class 2" (P1)

"I used drugs cannabis type first and then subsequently uses Shabu-Shabu" (P1)

"Initially I use Marijuana just to try it" (P1)

"After that I was hooked and feel comfortable and not like there is a burden"(P1).

Then proceed with the second statement from the next participant who said that:

"I used the Shabu-Shabu while working as a driver" (P2)

"Friend introduced the drug was when I felt tired, after using it I feel strongly bring the cars "(P2)

"I was the object of hope family because I wrote it should work drudge "(P2).

Other categories that depict drug use it is as follows in accordance with the interview in depth with next participants:

"I used the Shabu-Shabu since I was in Makassar" (P3)

"Then I moved to Nabire to work as part of Loading in the airline Wings Air in Nabire" (P3).

"We bought a package from a ship in the port of Nabire twice a month by worth 3 million dollars ". (P3).

"I used the Shabu-Shabu in Nabire for reasons of job that must be hard work"(P3).

"If use of Shabu-Shabu because I feel strongly in the work" (P3)

Another additional category says about the cause consume drug is in accordance with the in-depth interview with one of the teens as follows, namely;

"I have just used Shabu-Shabu when completed high school" (P4)

"I feel hate and exasperated with the state of my home" (P4)

"My parents were too busy with his job" (P4)

"They have a lot of outside the home, and rarely spent time with us "(P4)

Theme 2: Supporting the cause factors of adolescent consumed drug in Papua and West Papua. The second theme will elaborate of supporting factors why teen consumed drugs in Papua and West Papua. Based on depth interviews with the participants obtained the results of the interview are as follows;

"I used the marijuana therefore try-just try it first" (P5)

"I have a lot of hanging out with friends outside of my complex" (P5)

"I feel that I am too restrained by my parents, everywhere is prohibited;

Ifeel the stress very heavy "(P5)

"Friend offers marijuana and made me want to try and feel comfortable using it because it seemed as if no problem " (P5)

An additional category that is elaborated when done in-depth interview is;

"I wear a Shabu-Shabu because my job" (P6) 
"I was the object of a family and have to work hard" (P6)

"If I used the Shabu-Shabu I am not sleepy and strong work "(P6)

"I get it from my close friends at the airport" (P6)

Other statements added by the other participant in doing depth interviews

"I used Shabu-Shabu as cause of work hard" (P7)

"I fell not a sense of tired if use Shabu-Shabu" (P7)

"Sa should work for the sake of the hope of the family" (P7)

\section{Discussion}

In this section, researchers will discuss and explain about the interpretation of research results, research done at the limitation moment, as well as the implications of the results of the research. Interprets discussion of the results of study have carried out by comparing the results of the study with a review of the literature which has been described in the previous chapter. Limitations of this research will discuss about the flaws and weaknesses, as well as the obstacles encountered by the researchers at the time of the execution of the research field. The implications of the results of the study discusses what can be further developed from the results of this research, especially to developing service-based transcultural nursing has to do with the behavior of consume drug among the age of the teenager in the Provinces of Papua and West Papua.

\section{Interpretation and Discussion of the results}

Researchers have identified two themes that are the result of this research. The themes identified by the purpose of the research. An overview of the results of research activities that have been carried out successfully identified two themes that are important in deciding the chain of drug use in the Provinces of Papua and West Papua. On this occasion will be shown in depth the causes of teenagers in Papua and West Papua consume drug as well as a supporting factor too.

The main causes of teen consume drug in Papua and West Papua. In this study found facts empirically through in-depth interviews with drug users that most teens consume drug underlying in Papua and West Papua are because the association and try among teenagers. They easily once affected by the state of the environment mainly by their association. This is in line with research conducted by Jimmy Simangungsong in 2015 in the town of Tanjung Pinang who said that factor causes teen consume drug is a factor of personality that is teen can't sort out which one good and should not have done [10]. It is similarity with research of Marta and Kevin [11] that one factor consume drug or experienced first-hand when hanging out with a friend near the neighborhood's newer townhouses.

Rogers (1974) in Notoadmodjo [12] revealed that before the person adopts a new behavior, the sequential process i.e. awareness, interest, judgments, try and adopt. Contacts with drugs often occur at the age of adolescence. Gathered with peers, and then when one of them consume drugs, then others will try it, might just want to know or also want shows his prowess.

The second thing that becomes a reference teen consume drug is due to the factor work for the sake of economic encouragement solidify their work in more established economies resulted in his family. This is in line with the study that they consume drugs because more resistant in the works. It also strengthened and sharpened by previous opinion by Clausen in 1957 at Narcotics Polyclinic in Mental Hospital who says that the psychological factor is as much as $48 \%$ or influential enough against drug abuse i.e. because of his work. The private workers need job demands, discipline, and high working ability [13]. Work in the field of private competition is also relatively higher compared to government staff. According to Baum [14], stress is a very negative emotional experiences with change of physiological, biochemical, and behavioral, designed to reduce or adjust itself against stressor by way of manipulating the situation, change the stressor or by accommodating the effect.

Then from the other interviews found that another very influential factor against drug use among teenagers in Papua and West Papua is due to the factor of the household in their troubled family where the flurry of parents and also the ugliness of the parent relationship can be a factor in the causes of the emergence of teenage desire in consume drugs. This is also in line with the research conducted in 2015 by May Wulandari in Jember, East Java where as many as $74.7 \%$ say that they consume drug due to family problems that are not intact.

Cause factor supporting teenage consume drug in Papua and West Papua

Based on the above themes and has done in an in-depth interview to get that one factor supporting teenage consume drug in the Provinces of Papua and West Papua is due to pressure and parental restraints against the child. Restraints against the child will make them rebel and find a way out in an environment where they will be accepted. This is in line with what in Wulandari wrotten in 2015 which says that environmental factors around which curb give contribution about $60.2 \%$ effect on drug use among teens. It is also in line with the 2009 Sumiati research said that the one that affects the involvement in drug use was due to depressed $[15,16]$.

According to Lazarus and Folkman in 1984 says that someone is trying to cope with the stress of having coping mechanisms to avoid or minimize their significance or forget the stressor through drug abuse [17].

\section{References}

1. Halvaksz Jamon, Lipset David. Another Kind of Gold: an Introduction to Marijuana in Papua new Guinea, The Australian Journal of Anthropology. 2006; 76: 209-219.

2. Alex Halvaksz Jamon. Cannabis and Fantasies of Development: Revaluing Raltaions through land in Rural Papua New Guinea, The Australian Journal of Anthropology. 2007; 18.

3. Reid G, Devaney, Baldwin M,S. ASIA PASIFIC COLUMN: Drug production, trafficking and trade in Asia and Pasific Island countries, The Australian Journal of Anthropology. 2006.

4. Cohen $T$ Paul. Symbolic dimensions of the anti-opium 
campaign in Laos, The Australian Journal of Anthropology. 2013; 24: 177-192.

5. National Narcotics Agency of Indonesia Authorities (BNN), Narcotics, Propinsi Papua, 2016.

6. Agussalim. Transcultural Nursing. Masyarakat ekonomi ASEAN, dan Caring serta Latihan Critical Thinking. Fitramaya, Yogyakarta. 2015.

7. http://jakartaglobe.id/tag/national-narcotics-agency-bnn

8. Sugiyono. Metode Penelitian Pendidikan Pendekatan Kuantitatif, Kualitatif, dan R\&D, Alfabeta Bandung, Cetakan ke. 2013.

9. Alfiyanti, Rahmawati, Milanti. Evaluating sexual nursing care intervention for reducing sexual dysfunction in Indonesian cervical cancer survivors, Asia-Pacific Journal of Oncology Nursing, 2016; 3: 266-271.

10. Simangungsong Jimmy. Penyebab Remaja Mengkomsumsi
Narkoba, Jurnal Kesehatan, Unpublised. 2015.

11. Marika, U Marta, Haggerty, D Kevin, \# it's Dangerous: The Online World of Drug Dealers, Rappers, and the Street Code. British Journal of Criminology. azx083. 2018.

12. Notoadmodjo, Pendidikan dan Perilaku Kesehatan, Rineka Cipta, Jakarta. 2003.

13. https://scholarship.law.duke.edu/cgi/viewcontent.cgi?article $=2703 \&$ context $=$ lcp

14. Baum. Stress, intrusive imagery, and chronic distress, Health Psychology, 1990; 9: 653-675.

15. Wulandari M. Remaja mengkomsumsi Narkoba, Jember. Unpublished 2015.

16. Sumiati. Asuhan Keperawatan pada Pasien Penyelahgunaan dan Ketergantungan NAPZA, Trans Info Media, Jakarta. 2009.

17. https://explorable.com/stress-and-cognitive-appraisal 